\title{
LINHAS GERAIS SOBRE DIREITO SUCESSÓRIO NA ANTIGUIDADE: DO EGITO AO DIREITO ROMANO
}

\author{
Débora Cristina Holenbach Grivot ${ }^{1}$
}

\section{INTRODUÇÃO}

Este artigo tem por objetivo discorrer a respeito do direito sucessório na Antiguidade. A ideia que se propõe afasta-se inteiramente da completude, tanto de argumentos como de fontes. O que se pretende é um sumário apontamento sobre as mais remotas formas de atribuir titularidade de bens a partir da morte do proprietário, verificando como, em linhas gerais, isso se deu nas civilizações mais antigas.

A abordagem é simples, pelo método de sinalização de características elementares da civilização e do direito que nela existe para então demonstrar as linhas gerais do direito sucessório do povo que se está observando. Neste procedimento, a primeira civilização que se analisa é a do antigo Egito. Em seguida, como demonstração da cultura mesopotâmica, analisa-se o direito da Babilônia, máxime o Código de Hamurabi. Logo em seguida, se observa o direito hebreu como forma de finalizar os povos do Oriente Próximo para, então, ser objeto de consideração, as linhas gerais do direito na Grécia Antiga. Por fim, o direito Romano. Este, pela sua grandiosidade, foi observado em sentido sumário e restritivo, com o único propósito de apontar a existência das mais ordinárias regras de direito no que tange ao direito sucessório.

1 Doutoranda em Direito Civil pela UFRGS, mestre em Direito Civil pela UFRGS, professora de Direito Romano e História do Direito das Faculdades São Judas Tadeu de Porto Alegre, Faculdade Dom Bosco de Porto Alegre e professora substituta por concurso público da Faculdade de Direito da UFRGS. 
Não seria possível, nesta sede, realizar investigação profunda acerca deste tema. Por isso, as próximas linhas pretendem mais do que demonstrar o direito sucessório, instigar a curiosidade e incentivar a pesquisa e o estudo dos direitos antigos como forma de demonstrar a historicidade do fenômeno jurídico, conforme será visto a seguir.

\section{PRIMEIRA PARTE: O DIREITO MAIS REMOTO - ANTIGUIDADE PRÉ- CLÁSSICA}

\section{ANTIGO EGITO E O DIREITO SUCESSÓRIO}

\subsection{Noções Gerais da história e do Direito no Antigo Egito}

Muitas são as divisões apresentadas pela historiografia como fases do Antigo Egito. Aquela adotada por John Gilissen (2008, p. 51) divide em $\left(1^{\mathrm{a}}\right)$ Antigo Império, (2a $)$ Médio Império e ( $\left.3^{\mathrm{a}}\right)$ Novo Império, sendo que cada uma delas tem, intercalado, um momento de transição.

Da mesma forma que a historiografia, riquíssima é a história geral daquela civilização. Como bem informa Rodrigo Palma (2001, p. 57):

O Egito dos faraós foi, senão o reino de maior projeção política na longa trajetória do Oriente Próximo, pelo menos um dentre os mais antigos a compor a história da humanidade. A geografia, vale dizer, muitíssimo concorreu para a veracidade dessa assertiva. Sabe-se que o Egito conheceu a primazia de poder desenvolver a sua notória civilização, às margens de um rio - "festejado Nilo" - que significava a diferença entre a vida e a morte para populações ribeirinhas essencialmente agrárias.

Ainda que não caiba esse assunto nesta etapa de estudo, enfocado no direito, vale dizer, com as palavras de Rodrigo Palma (2001, p. 57):

Os egípcios destacaram-se de modo evidente nas artes, arquitetura, medicina e agricultura. Mas, apesar de toda a grandeza a eles atribuída por gerações de pesquisadores, é fato que, no âmbito do Direito, deixaram exígua contribuição. Sendo assim, quais foram as razões, pois, que os fizeram a distanciar-se da prática legislativa, arvorada com tanta ênfase por praticamente todas as nações que os rodeavam? Grimberg será o primeiro a buscar lançar luz ao problema. O autor, diligentemente informa: "Apenas uma coletânea de leis do Egito Antigo chegou até nós; é, além disso, muito incompleta". Logo adiante, o mesmo declara: "infelizmente - e é o caso de muitas outras perdas - o texto está tão estragado que nenhum parágrafo completo chegou até nós". Giordani também admite: "Não é fácil sintetizar a História do Direito no Egito Antigo por duas razões: a longa duração da história do país que assistiu a inúmeras transformações das instituições políticas e sociais e a 
carência de coleções legislativas tais como as que encontramos referentes à vida jurídica dos povos da Antiga Mesopotâmia".

A respeito do direito, o Egito não transmitiu à modernidade códigos ou livros jurídicos. Para Gilissen (2008, p. 52):

o nosso conhecimento do direito egípcio é baseado quase exclusivamente nos actos da prática: contratos, testamentos, decisões judiciárias, actos administrativos etc. Os egípcios quase nada escreveram de livros de direito, nem deixaram compilações de leis ou costumes. Mas não deixaram de se referir frequentemente a "leis"; essas leis deviam ser escritas, pois, em período de confusão, foram lançadas á rua, "espezinhadas" e "laceradas".

Mas o certo é que, foi a primeira civilização na história da humanidade que desenvolveu um sistema jurídico que pode chamar-se de individualista, rompendo com as solidariedades ativas e passivas dos direitos arcaicos e feudais (Gilissen, 2008, p. 52).

\subsection{A sucessão no Antigo Egito}

Na primeira fase, as características da família determinam diretamente $o$ direito sucessório. A família no Antigo Império Egípcio era formada pelo pai, pela mãe e pelos filhos, sendo que o casal apresenta-se em pé de igualdade (não há prevalência do homem na família), podendo ambos dispor do próprio patrimônio em vida ou após a morte (Gilissen, 2008, p. 55). De outra parte, não há distinção entre os filhos, nem de gênero nem mesmo primogenitura. Além de poder ter patrimônio próprio, o filho tem liberdade de dispor do mesmo. Quanto às regras sucessórias, sabe-se que a liberdade de testar é completa (Gilissen, 2008, p. 55).

$\mathrm{Na}$ segunda fase, ainda com raízes no período anterior, a evolução do direito no sistema jurídico egípcio direciona-se à formação de uma oligarquia sacerdotal, com hereditariedade dos cargos, onde a evolução do direito público corresponde à evolução paralela do direito privado: poder paternal e marital, desigualdade nas sucessões pela primogenitura e privilégio da linha masculina.

$\mathrm{Na}$ terceira fase, deixando de lado o regime feudal fechado, o direito egípcio evolui novamente para a preponderância da lei, da igualdade jurídica dos filhos e filhas, liberdade para dispor do patrimônio em vida e depois da morte. Ao final, depois da ocupação persa e romana, tal regime é tolerado por um período, até que então sucumba ao poderio romano.

\section{OS DIREITOS CUNEIFORMES}

\subsection{Noções gerais}

Chama direitos cuneiformes o conjunto dos direitos da maior parte 
dos povos do Oriente Próximo da antiguidade que utilizaram de um tipo de escrita parcialmente ideográfica em forma de cunha, tendo como língua culta a acádica (Gilissen, 2008, p. 58). Por isso, é possível afirmar que não há um direito cuneiforme único, mas conjunto de sistemas jurídicos de diferentes regiões localizadas na Mesopotâmia.

Dos povos que habitavam a região, tem destaque o povo babilônico em face do famoso Código de Hammurabi, que não é o mais remoto, mas com certeza é o mais famoso e também o mais completo e extenso. Segundo John Gilissen (2008, p. 61): "o monumento jurídico mais importante da antiguidade antes de Roma é o Código de Hammurabi (rei da Babilônia, possivelmente entre 17261686 a.C.). O texto provavelmente redigido por volta de 1694 a.C, está gravado numa estela descoberta em Susa, em 1901, e atualmente conservada em Paris no Museu do Louvre".

Trata-se de uma compilação dos costumes já vigentes entre os povos mesopotâmicos e contém 282 parágrafos, iniciando-se pelo direito penal e depois regulando as relações de agricultura e domésticas, comércio, casamento e herança, contratos de parceria e arrendamento agrário, limites de preços, juros e salários e, por fim, normas sobre o regime escravo. Para Gilissen (2008, p. 63):
O Código de Hammurabi e os numerosos atos da prática do mesmo período dão-nos a conhecer um sistema jurídico muito desenvolvido, sobretudo no domínio do direito privado, principalmente dos contratos. [...] Subsistem no entanto, na época de Hammurabi, sobrevivências do período anterior, por exemplo, na medida em que o poder paternal é mais extenso do que no Egipto (o pai insolvente podia entregar a sua mulher ou os seus filhos ao credor para que eles trabalhassem ao seu serviço), ou ainda no facto de a poligamia subsistir, permitindo ao marido cuja esposa é estéril tomar uma outra mulher, e enfim, na medida em que o direito penal continua extremamente severo.

Além disso, o texto legal propriamente dito distingue as diferentes classes das pessoas em: "awilun", o senhor, "muskenun", plebe livre e escravos, estabelecendo em cada caso diferentes sanções, conforme a classe da pessoa.

Do estudo do Código de Hammurabi deriva duas hipóteses distintas. Para a primeira, o imperador simplesmente desenvolveu melhor a legislação de códigos vigentes em períodos anteriores, classificados como "Direito babilônico pré-hammurabiano", ou seja, desvalorizando a inteligência de seu criador. A outra hipótese seria aquela mesma acentuada no proêmio do Código, segundo o qual Hammurabi ditou o Código sob direta inspiração divina e como um justiceiro e protetor dos fracos: "Como Marduk [Deus pro- 
tetor dos babilônios] me encarregou de reger o povo com justiça e de dar uma direção ao país, dei ao país ordem jurídica e justiça, dei aos habitantes bem-estar. E então ordenei: [...]."

Pela grandiosidade da obra, como dizia o próprio, é impossível concordar ter sido uma simples "cópia", com algumas alterações. Hammurabi foi, de certa forma, um criador de muitos princípios, não só judiciais, mas que em sua teoria possuíam temas que hoje são abordados de forma parecida.

\subsection{Direito Sucessório}

No que diz respeito ao direito sucessório especificamente, Ronaldo Leite Pedrosa (2008, p. 79) afirma que, pelo fato de o testamento não estar contemplado de forma expressa no código, pressupõe-se que tal instituto (testamento) não existia no direito mesopotâmico com as características de hoje. Mas o mesmo autor ressalva a importância da interpretação do parágrafo 150, que tem a seguinte redação:

$\S 150$ : Se um awilum deu de presente à sua esposa um campo, pomar, casa ou um bem móvel e deixou-lhe um documento selado, depois (da morte) de seu marido, os seus filhos não poderão reivindicar contra ela. A mãe dará a sua herança aos filhos que ama, mas não poderá dá-la a um estranho.

Para Ronaldo Leite Pedrosa (2008, p. 80), a expressão “documento selado" lida em conjunto com a ideia de "ser aberto após a morte" do homem que o redigiu, faz aproximar do instituto moderno do testamento.

Porém, no que diz respeito à sucessão legítima, outros parágrafos do Código revelam algum esboço de sistema hereditário. Passamos a analisá-los.

\section{Herança da Mulher}

$\S 162$ : Se um awilum tomou uma mulher como esposa e ela the gerou filhos e (depois) essa mulher morreu, seu pai não poderá reclamar o dote, seu dote é de seus filhos.

$\S$ 163: Se um awilum tomou uma mulher como esposa e ela não the obteve filhos e (depois) morreu, se seu sogro lhe devolveu a terhatum, que esse awilum enviara para a casa de seu sogro, seu marido não poderá reclamar o dote desta mulher. Seu dote é da casa de seu pai.

$\S 164$ : Se seu sogro não lhe devolveu a terhatum, ele deduzirá do seu dote $\mathrm{o}$ correspondente à sua terhatum e restituirá o seu dote à casa de seu pai.

Segundo as explicações de Emanuel Bouzon, (1987, p. 160) estes parágrafos citados tratam do falecimento da esposa antes do marido, e regulamentam a devolução ou não do dote que a mulher trouxe da casa do seu pai:

o $\S 162$ trata do caso de uma mulher que teve filhos no seu casamento. A lei determina "a seriktum é de seus filhos". Depois da morte da mãe, os 
filhos herdam, automaticamente, a seriktum de sua mãe. Mas para evitar qualquer reivindicação por parte da família da esposa morta, a lei acrescenta a cláusula: "seu pai (da mulher) não poderá reclamar o seu dote".

Se houver filhos, estes herdam automaticamente. Se não houver filhos, o procedimento depende da conduta do sogro vivo ter ou não devolvido um preço que o marido "pagou" pela esposa (terhatum). Se devolveu, então o marido deve devolver o dote integralmente, se não devolveu, o marido tem o direito de deduzir o valor já pago pela esposa do dote a ser devolvido ao pai dela (Bouzon, 1987, p. 160).

\section{Igualdade entre os filhos do homem}

$\S$ 165: Se um awilum deu de presente a seu herdeiro preferido um campo, um pomar ou uma casa e escreveu para ele um documento selado, depois que o pai morrer, quando os irmãos dividirem, ele tomará o presente que o pai lhe deu; além disso, dividirão os bens da casa paterna em partes iguais.

$\S 166$ : Se um awilum tomou esposas para os filhos que teve e para o filho menor não tomou uma esposa, depois que o pai morrer, quando os irmãos dividirem (a herança), dos bens da casa paterna eles colocarão à disposição de seu irmão mais novo, como adicional à sua parte, a prata da terhatum e fá-lo-ão tomar uma esposa.
$\S$ 167: Se um awilum tomou uma esposa, ela lhe gerou filhos e (depois) essa mulher morreu, se depois de sua morte ele tomou outra mulher e ela (lhe) gerou filhos, depois que o pai morrer, os filhos não dividirão conforme as mães. Eles tomarão o dote de suas mães e os bens da casa paterna eles (os) dividirão em partes iguais.

\section{Deserdação}

$\S$ 168: Se um awilum resolveu deserdar seu filho e disse aos juízes: "eu quero deserdar meu filho", os juízes examinarão a questão. Se o filho não cometeu uma falta suficientemente grave para excluí-lo da herança, o pai não poderá deserdar o seu filho.

$\S 169$ : Se ele cometeu contra seu pai, uma falta suficientemente grave para excluí-lo da herança, a primeira vez eles o perdoarão. Se, pela segunda vez, ele cometeu uma falta grave, o pai poderá deserdar seu filho.

\section{Legitimação dos filhos e \\ sucessão}

$\S 170$ : Se a primeira esposa de um awilum the gerou filhos e a sua escrava lhe gerou filhos, (se) o pai, durante a sua vida, disse aos filhos que a escrava lhe gerou: "vós sois meus filhos" e contou com os filhos da primeira esposa, depois que o pai morrer, os filhos da primeira esposa e os filhos da escrava dividirão em partes iguais os bens da casa paterna, mas o herdeiro, filho da primeira esposa, escolherá entre as partes e tomará para si.

$\S$ 171a: Mas se o pai, durante a sua vida, não disse aos filhos que a 
escrava the gerou: "vos sois meus filhos" depois que o pai morrer, os filhos da escrava não dividirão os bens da casa paterna com os filhos da primeira esposa. Será efetivada a libertação da escrava e de seus filhos. Os filhos da primeira esposa não poderão reivindicar os filhos da escrava para a escravidão.

\section{Posição da Primeira esposa}

$\S$ 171b: A primeira esposa tomará consigo o dote e o presente nupcial que o esposo lhe deu e registrou numa tábua. Ela morará na casa de seu marido e enquanto viver terá usufruto. Não poderá vender; sua herança é de seus filhos.

$\S 172$ : Se seu marido não lhe deu um presente nupcial, devolver-lhe-ão seu dote integralmente e ela tomará dos bens da casa de seu marido a parte correspondente a de um herdeiro. Se seus filhos a maltratarem para fazê-la sair de casa, os juízes examinarão sua questão e imporão uma pena sobre os filhos: essa mulher não sairá da casa de seu marido. Se essa mulher resolveu sair, deixará para seus filhos o presente nupcial que seu marido lhe deu e levará consigo o dote da casa de seu pai, o marido de seu coração poderá esposá-la.

\section{Igualdade dos filhos em relação à herança da mãe}

$\S 173$ : Se essa mulher, lá onde entrou, gerou filhos a seu segundo marido, (e) depois essa mulher morreu, os filhos do primeiro e do segundo (casamento) dividirão o seu dote.

$\S$ 174: Se não gerou filhos a seu segundo marido, os filhos do seu primeiro marido receberão seu dote.

\section{O DIREITO SUCESSÓRIO HEBRAICO}

\subsection{Noções Gerais da História e do Direito Hebreu}

Os hebreus foram um povo semita que vivia na região da Palestina em tribos nômades, conduzidas por chefes familiares. Está descrito no Êxodo a sua condução como escravos ao Egito e depois o retorno à Palestina, sob a guia de Moisés, por volta de 1500 a.C., que recebeu as tábuas da lei (os dez mandamentos), base do direito hebreu. Eram diferentes por seus costumes, mas principalmente por retratarem-se como o povo escolhido por Deus, único e onipotente. Assim, para os hebreus, ao contrário de outros povos da região, não existia diferença de classes, todos eram irmãos, filhos de Deus e de direitos iguais perante Ele.

Uma vez que a lei divina é proclamada por Deus, sendo imutável, segundo as disposições religiosas a organização social, política e jurídica é estabelecida pelo autor supremo. Estas disposições compõem a Torah: os cinco primeiros livros da Bíblia também chamados de Pentateuco. Neles, Gênesis trata do início da criação do mundo e vida dos patriarcas; Êxodo trata do cativeiro no Egito, os Dez Mandamentos e o Código da Aliança; Levítico trata do conjunto de prescrições religiosas e culturais; Números trata da descrição da organização das 
tribos hebraicas e Deuteronômio é a repetição da lei, livro que completa os quatro anteriores. Esta é a mais primitiva organização jurídico-religiosa do povo hebreu.

\subsection{A Sucessão descrita no Direito Hebreu Antigo}

\section{a) Primogenitura e Sucessão}

Ainda dentro da lei de família podemos considerar alguns aspectos quanto a questão de sucessão e herança. De modo geral, a liderança era transmitida ao filho mais velho quando da morte do pai. No entanto, essa passagem não era automática, tendo de ser conferida pelo pai mediante uma bênção especial (Gênesis 27:29,37). Porém, era permitida ao pai a liberdade de escolher um filho mais novo como seu sucessor no caso de considerar o mais velho indigno para a função (Souza, 2008, p. 62).

Com respeito à partilha da herança, Deuteronômio 21:15-17 determinava que $o$ primogênito tinha direito a duas partes de tudo que o pai possuísse sendo o restante dividido em partes iguais com os demais filhos, incluindo inclusive, os filhos das concubinas (estes indicados em Genesis 25:5-6). A passagem apresenta o seguinte texto:

Deut. 21:15-17: Se um homem tiver duas mulheres, uma que ele ama, outra que ele desdenha, e lhe tiverem dado filhos, tanto a que é amada como a que é desdenhada, se o filho desta última for o filho primogênito, esse homem, no dia em que repartir seus bens entre os seus filhos, não poderá dar o direito de primogenitura ao filho da que é amada, em detrimento do primogênito, filho da mulher desdenhada. Mas reconhecerá por primogênito o filho da mulher desprezada, e dar-lhe-á uma porção dupla de todos os seus bens, porque esse filho é o primeiro fruto de seu vigor, é a ele que pertence o direito de primogenitura.

\section{b) Herança das mulheres}

$\mathrm{Na}$ ausência de filhos homens, as filhas passavam a ter direitos sobre a herança desde que estivessem casadas com pessoas do próprio clã (Números 27:1-11).

Aproximaram-se então as filhas de Salafaad, filho de Hefer, filho de Galaad, filho de Maquir, filho de Manassés, filho de José. Seus nomes eram Maala, Noa, Hegla, Melca e Tersa. Elas apresentaram-se diante de Moisés e do sacerdote Eleazar, e diante dos principais e de toda a assembleia, à entrada da tenda de reunião: "Nosso pai, disseram elas, morreu no deserto, e não tomou parte na sedição excitada por Coré contra o Senhor; mas morreu por causa de seu próprio pecado. Ora, ele não teve filhos. Por que razão há de desaparecer o nome de sua família, por não ter tido filho algum? Dá-nos uma propriedade entre os irmãos de nosso pai." Moisés levou a sua causa diante do Senhor, que lhe disse: "As filhas de Salafaad têm razão. 
Dar-lhes-ás uma propriedade como herança entre os irmãos de seu pai, para que elas lhe sucedam na herança. Dirás aos israelitas: se um homem morrer sem deixar filhos, a herança passara à sua filha; se não tiver filhas, será dada aos seus irmãos. Se não tiver irmãos, a herança passará aos irmãos de seu pai, e se seu pai não tiver irmãos, será dada ao seu parente mais próximo em sua família, e este último tornar-se-á seu possessor. Esta será para os filhos de Israel uma prescrição de direito, assim como o Senhor ordenou a Moisés”.

\section{c) Ressalva de o patrimônio continuar no clã}

No entanto, normalmente não possuíam direitos sobre qualquer parte das propriedades do pai de modo a evitar que parte dos bens de uma família se transferisse para outra família pelo casamento (Números 36).

Números 36: Os chefes de família dos filhos de Galaad, filho de Maquir, filho de Manassés, da raça de José, apresentaram-se diante de Moisés e dos principais chefes das famílias israelitas: "O Senhor, disseram eles, ordenou ao meu senhor que desse, por sorte, a terra em herança aos israelitas; e o Senhor ordenou ao meu senhor que desse às filhas de Salfaad, nosso irmão, a herança devida ao seu pai. Mas se homens de outra tribo as receberem por mulheres, a sua herança será retirada do patrimônio de nossos pais e acrescentada ao da tribo na qual elas se casarem; e assim será diminuída a nossa herança.
Quando chegar o jubileu dos filhos de Israel, a sua herança será unida à da tribo a que pertencerem, e separada da de nossos pais". Moisés, então, respondeu aos filhos de Israel por ordem do Senhor: "Tem razão a tribo dos filhos de José. Eis a ordem do Senhor para as filhas de Salfaad: casem com quem quiserem, contanto que seja com alguém de uma família da tribo paterna; desse modo as possessões dos israelitas não passarão de uma tribo à outra, e cada israelita ficará na herança da tribo de seus pais. Todas as mulheres que possuírem um patrimônio em uma tribo israelita, tomarão marido na tribo paterna, a fim de que cada israelita conserve o patrimônio de família. Herança alguma poderá passar de uma tribo à outra: deve cada tribo israelita permanecer no que é seu". As filhas de Salfaad comportaram-se segundo a ordem do Senhor. Maala, Tersa, Hegla, Melca e Noa, filhas de Salfaad, casaram-se com filhos de seus tios; casaram-se, pois, em famílias saídas de Manassés, filho de José, e a possessão que lhes tocava permaneceu na tribo de seu pai. Tais são as leis e as ordenações que o Senhor transmitiu aos israelitas por intermédio de Moisés nas planícies de Moab, perto do Jordão, defronte de Jericó.

Não existe na Tanakh qualquer menção a respeito do pai herdar bens dos filhos na morte deste. Uma possível explicação é a de que enquanto o pai estivesse vivo, o filho não possuiria bens (Souza, 2008, p. 62). 


\section{O DIREITO SUCESSÓRIO NA GRÉCIA ANTIGA}

\subsection{Noções Gerais da História e do Direito Grego}

A península balcânica, região costeira com difícil acesso, cercada de montanhas e com agricultura complicada abrigou, por volta de 2000 a.C., uma migração de povos guerreiros vindos da Ásia Menor via mar Egeu para a região que denominaram de Grécia. Graças ao aspecto geográfico, duas consequências podem ser identificadas. A primeira diz respeito ao fato dessas dificuldades impulsionarem o povo grego a desenvolver métodos de sobrevivência, criando rico comércio e poderosos exércitos. A segunda consequência pode ser vista como um resultado geopolítico, já que, isoladas, as localidades desenvolveram políticas unitárias - as polis. Assim, a Grécia Antiga jamais foi um estado unificado (desconsiderando o império de Alexandre Magno), pois era dividida em diversas cidades-estados que comerciavam e guerreavam entre si, cada qual com sua cultura e traços diferenciados, umas bélicas (Esparta) outras voltadas para o pensamento (Atenas), cada uma com suas formas de governos diferenciados. Diante dessas características diferenciadas, o direito na Grécia não poderia ser diferente: cada polis tinha suas regras jurídicas e ornamentos próprios, não havendo uma uniformidade.

\subsection{A sucessão na Grécia antiga}

\section{a) Problemática das fontes}

Talvez em face da prevalência do aspecto político e não propriamente jurídico dos traços gregos, não há muita bibliografia a respeito do direito legislado. Assim, a formulação do conhecimento se dá muitas vezes por reconstituição de fontes e informações historiográficas externas. A maior delas parece ser a famosa obra de Fustel de Coulanges, A Cidade Antiga, demonstrando que é preciso considerar a força da contribuição religiosa para a formação do direito antigo. Tal é verdade, principalmente na ideia de que a propriedade e sucessão são decorrentes desta concepção religiosa da vida (Coulanges, 2012, p. 12).

\section{b) Legislador Sólon e o direito sucessório}

$\mathrm{Na}$ reforma legislativa que ocorreu em Atenas, foram destaque os personagens de Drácon (cerca de 620 a.C.) e de Sólon (cerca de 594/593 a.C.). Das Leis de Drácon, cujos textos se perderam, sabe-se que no âmbito penal elas seriam muito rígidas (daí o epíteto "leis draconianas"). Sabe-se, também, que elas puseram fim ao sistema de gens e clãs patriarcais. Sobre as Leis de Sólon três medidas foram mais populares: primeiro, a proibição da servidão pessoal por dívidas; segundo, a possibilidade de qualquer pessoa mover ação contra quem lhe causou injustiça e, terceiro, o direito 
de apelo à Assembleia Popular. Esta última foi referida especialmente por Aristóteles como fator de fortalecimento de um povo: "pois quando o povo se assenhora dos votos, assenhora-se do governo" (In: Constituição de Atenas, Capítulo IX).

No que diz respeito especificamente ao direito sucessório, novamente, muita controvérsia. A esmagadora maioria dos textos jurídicos que abordam a temática, o fazem superficialmente. Segundo Guilherme Braga da Cruz (1979, p. 55):

Tratava-se de um sistema de parentela combinado com o privilégio de masculinidade, de forma que a parentela do lado materno só é chamada à sucessão depois de esgotadas todas as do lado paterno, e sempre com preferência do sexo masculino sobre o feminino.

Ainda, existia na Grécia antiga o instituto do "Epiclerado" (1979, p. 56) que consistia na circunstância pela qual, não havendo herdeiros homens, cabia à filha que sucederia na linha paterna a obrigação de casar-se com o mais próximo dos parentes agnatícios do seu pai, para, assim, gerar um descendente da mesma estirpe, considerado para fins jurídicos e religiosos filho do avô materno (pai da epiclera) e que nesta qualidade continuaria seu culto doméstico, receben- do sua herança logo que atingisse a maioridade.

Além disso, a reforma legislativa de Sólon introduz o direito de dispor por testamento, já que como visto, o patrimônio hereditário é obrigatoriamente transmitido aos homens que pertencem ao mesmo grupo familiar religioso. Uma ressalva é válida: tal disposição somente pode ser considerada na falta de filhos naturais. Alguns autores referem à circunstância do testamento estar ligado mais à amizade do que ao parentesco (Nascimento, 2009, p.77):

No direito grego, a sucessão por testamento só era reconhecida no caso exclusivo da falta de filhos. Pelo menos, a partir de Sólon, era esta a regra do direito sucessório em Atenas, segundo informação que nos vem de Plutarco. Uma outra lei famosa é aquela que concerne aos testamentos: outrora não eram permitidos; os bens e as casas deviam permanecer no genos do defunto. Sólon permitiu aos que não tivessem filhos dar seus bens a quem o desejassem; assim, ele preferiu a amizade ao parentesco, a livre beneficência ao constrangimento.

Desta forma, o direito sucessório num período mais remoto como o da reforma legislativa em Atenas esteve atrelado mais ao conteúdo da vontade do testador do que aos lações de sangue ou parentesco 


\section{SEGUNDA PARTE: NOÇÕES GERAIS DE DIREITO SUCESSÓRIO ROMANO}

\section{NOÇÕES GERAIS}

Se compreende-se por sucessão em geral, a substituição de uma pessoa por outra em determinada relação jurídica, de forma plena o Direito Romano criou, desenvolveu e estabeleceu esse direito para a posteridade. Tanto na modalidade de sucessão universal, quando se transmite uma universalidade, como na modalidade singular, quando se transmite uma determinada relação jurídica ou um conjunto delas sem ser uma universalidade, foi criação do direito romano (Kaser, 1999, pg. 365). Ainda, existiu no direito romano tanto a sucessão inter vivos quando em vida das pessoas envolvidas, como nos casos de capitis deminutio, adrogatio e convenção de manus, como a sucessão causa mortis quando ocorre por causa da morte de alguém (Alves, 2007, p. 703).

No direito romano eram requisitos para a sucessão universal mortis causa, de natureza subjetiva (circunstâncias que se referem à pessoa do falecido e à pessoa do herdeiro), a capacidade para ter herdeiros, a capacidade para ser herdeiro e a capacidade para aceitar a herança. De natureza objetiva (circunstâncias, independentes das pessoas do falecido ou do her- deiro, que possibilitam a ocorrência da sucessão), eram requisitos da hereditas a morte de alguém, a delação da herança e a aceitação da herança pela pessoa a quem foi deferida. Estas disposições foram aplicadas no direito romano em conjunto com as demais regras que se passa a analisar (Alves, 2007, p. 703).

\subsection{Conceito e conteúdo da hereditas}

Originariamente ou primitivamente, a palavra heres designava a pessoa indicada pelo paterfamilias que era chamada a ficar no seu lugar quando este morresse, administrando e gerindo toda a hereditas que consistia justamente no conjunto de todos os poderes do pater falecido (Alves, 2007, p. 704):

Quanto à palavra herança (hereditas), além de designar o fato simplesmente da sucessão universal mortis causa, pode ser empregada em dois sentidos: a) no objetivo, designando o patrimônio de uma pessoa que faleceu - hereditas, ao menos nos direitos pós-clássico e justinianeu, se usa, nessa acepção, como universitas iuris (universalidade de direito); ou b) no subjetivo, significando o direito subjetivo de que alguém (heres - o herdeiro) é titular com relação a esse patrimônio; hereditas nesse sentido se utiliza como ius sucessionis (direito de sucessão). Para CarIo Longo e Bonfante (e a maioria dos romanistas os acompanha), hereditas, no direito 
clássico, não era empregada, em sentido objetivo como universitas iuris, o que só foi ocorrer no direito pós-clássico, quando teria surgido a distinção entre sucessão singular e sucessão universal. Por outro lado, em síntese, são objeto da hereditas em sentido objetivo todas as relações jurídicas (inclusive algumas de caráter extrapatrimonial) de que era titular o falecido, exceto as que são intransmissíveis por força de lei expressa, ou de sua extinção pela morte de seu titular. Assim, quanto às relações jurídicas patrimoniais, são elas, em regra, transmissíveis ao herdeiro; excetuam-se, porém, pelo seu caráter personalíssimo, o usufruto, o uso, a habitação, as obrigações do sponsor e do fideipromissor, e as obrigações decorrentes do delito (são estas sempre intransmissíveis do lado passivo - o débito -, mas nem sempre do lado ativo - o crédito); demais, com a morte de um dos contratantes, extingue-se, por via de regra, o contrato de sociedade e o de mandato. Intransmissíveis, também, são as relações jurídicas familiares, como, por exemplo, a tutela; e as de direito público, como a magistratura desempenhada pelo falecido.

Por isso, a origem da sucessão hereditária se apresenta muito conexa com o direito de família, já que a sucessão mortis causa se apresentava como a perpetuação da própria família. Assim, a finalidade originária e primordial da sucessão hereditária não era a transmissão do patrimônio do falecido, mas a de assegurar a continuidade do grupo familiar
(Schulz, 1960, p. 202). Passado o tempo, com o desenvolvimento e a modificação da família, muda também a natureza da hereditas, sem, contudo, perder a conexão com a sua origem:

D.50.17.62: Hereditas nihil aliud est, quam successio in universum uis quod defunctus habuerit.

D.50.17.62: A hereditas não é outra coisa senão a sucessão no complexo de direitos que teve o falecido.

Assim, o testamento, isto é, a designação do novo chefe que assumirá a família com a morte do pater, exerceu na primitiva família romana a importante função de preservação. No ius civile, a sucessão regular e prevalente é a testamentária. Se não houver deixado testamento, a herança do de cujus vai para os agnados e não havendo esses para os gentiles (época arcaica):

Tábua 5, passo 4: Se morre intestado quem carece de um "herdeiro seu", tenha a herança o agnado mais próximo. Passo 5: Se não existe agnado, recorram a herança aos gentis.

$\mathrm{Na}$ época clássica a herança transformou-se de "política" para "patrimonial", além de surgir a permissão de instituir-se herdeiro fora da família. Em face da exclusão dos filiusfamilias ou agnados emancipados da herança intestada, assim como os cognados, se instaura, pela atividade pretoriana, um novo sistema fundado em princípios 
de equidade e consoante o conceito moderno de sucessão no patrimônio: é a chamada bonorum possessio, que surge como contraposição ao direito civil e a sua finalidade primeira é a de ampliar a ordem da vocação hereditária (Alves, 2007, p. 708).

No direito pós-clássico são modificados os direitos civil e pretório até chegar na fusão dos dois sistemas. Com as Novelas 118 e 127 se instaura uma nova ordem sucessória na qual triunfa o princípio da cognação, os direitos dos legítimos se coloca no primeiro plano por força de razões morais, caindo em desuso as solenidades de instituição do herdeiro e em geral as formas antigas de testamento (Alves, 2007, p. 709).

\subsection{Concepção dogmática da herança}

Para os romanos, "succedere" não significa somente "seguir", mas seguir ou continuar uma situação jurídica. Por isso que, juridicamente, successio significa não apenas a transferência de um direito, mas a entrada de uma relação, o preenchimento de uma posição jurídica (Kaser, 1999, p. 365).

Assim, segundo o direito romano, é possível afirmar que no Direito Arcaico, o sucessor se coloca na mesma posição jurídica do antecessor; que o sucessor adquire um patrimônio em bloco, e de modo mediato, isto é, por consequência da aquisição de uma potestas a título de heres (herdeiro); e que do antecessor passam ao sucessor toda a sorte de direitos, inclusive os que de outro modo seriam intransmissíveis (D’Ors, 2006, p. 327).

No Direito Clássico, a única forma de sucessão que os romanos conheceram foi a sucessão universal (só no direito pós-clássico surgirá a sucessão singular), sendo que o sucessor recebia tanto os créditos como os débitos do sucedido e deveria pagar inclusive com o seu patrimônio (Schulz, 1960, p. 203).

\subsection{A Bonorum Possessio}

Ao lado da herança civil (hereditas) existe a herança pretória, a chamada bonorum possessio, que consiste na posse das coisas hereditárias conferidas pelo Pretor a determinadas pessoas e com fins que ora respondem aos velhos princípios da família agnatícia, ora aos novos de parentesco cognatício e do vínculo matrimonial (Schulz, 1960, p. 206). A obra do Pretor não tem por objeto, a princípio, reformar o direito sucessório civil, mas regular a posição das partes numa controvérsia hereditária (Alves, 2007, p. 711). Acerca das diferenças entre a bonorum possessio e a hereditas, Moreira Alves retrata o seguinte (2007, p. 711):

a) o bonorum possessor dispõe, contra os devedores do de cujus, apenas das 
ações do herdeiro concedidas por via útil (eram, em geral, actiones ficticiae), e isso porque na bonorum possessio não há, em rigor, successio (o bonorum possessor, à diferença do heres, não substitui o de cujus na posição jurídica por este então ocupada); b) o bonorum possessor - ao contrário do que ocorre com o herdeiro - não adquire a propriedade quiritária sobre os bens hereditários, mas apenas a propriedade pretoriana (posteriormente, por usucapião, pode ele transformar-se em proprietário quiritário desses bens); c) O heres adquire a herança ipso iure, ou mediante simples declaração de vontade independente de prazo: o bonorum possessor somente obtém a bonorum possessio se a requerer ao magistrado dentro de certo prazo, que, em geral, é de cem dias; e d) a bonorum possessio pode ser obtida por meio de representante; o heres não pode ser representado na aquisição da herança.

A bonorum possessio não é mais do que a adjudicação interina das coisas hereditárias a fim de facilitar a instauração do processo quando é duvidosa ou equívoca a situação de fato nas quais deve centrar-se. Importa, em tal caso, que o Pretor designe aquele que tem de possuir a herança e tem de ocupar a posição mais favorável de demandado. Depois de uma indagação sumária, o Pretor confere a posse para aquele que considera como herdeiro e que, se não é, sucumbindo no processo principal subsequente, no qual se discute sobre o fundo, terá de restituir a herança, a não ser que no intervalo tenha feito a chamada usucapio pro herede. Por não ser definitiva, a adjudicação do patrimônio hereditário (que o herdeiro pode cobrar por meio de uma hereditas petitio) se diz que a bonorum possessio é sine re (Kaser, 1999, p. 371).

$\mathrm{Na}$ época clássica, a função do Pretor é fundamentalmente corretora, conferindo os bens hereditários a pessoas que o direito civil não contempla como herdeiros (Alves, 2007, p. 713). Para que tal concessão ou adjudicação não resulte vazia, o magistrado outorga sua proteção também frente aos herdeiros civis, negando a estes o direito que lhes assiste (denegatio actionis) como também facultando ao bonorum possesor a oposição da exceptio doli na hereditas petitio, e assim, junto da bonorum possessio sine re, aparece a bonorum possessio cum re (Schulz, 1960, p. 2.067). A bonorum possessio pode ser conferida em conformidade com o testamento (bonorum possessio secundum tabulas), ou em ausência deste (bonorum possessio sine tabulis ou ab intestato), ou contra o disposto no testamento (bonorum possessio contra tabulas) (Alves, 2007, p. 714):

No direito justinianeu, embora os textos que se encontram no Corpus Iuris Ciuilis ainda se refiram ora à bonorum possessio ora à hereditas e não haja uma constituição imperial que, 
taxativamente, equipare a bonorum possessio à hereditas, a equiparação, na realidade, está realizada, continuando-se somente a dar denominação exclusiva de bonorum possessio às hipóteses de concessão provisória e à sucessão legítima dos cônjuges.

\subsection{A delação da herança no Direito Romano}

No direito Romano, delação é o chamamento feito a uma ou mais pessoas para adquirir uma determinada herança. A herança é deferida ou oferecida, os romanos chamam de $d e-$ ferre hereditatem e de vocare ad hereditatem e afirmam que se entende deferida a herança que uma pessoa pode conseguir adir (D’Ors, 2006, p. 329).

Assim, a herança se defere por testamento ou pela lei. Hoje chamamos de herança testamentária ou herança legítima, o que não corresponde ao sentido romano, já que o sentido romano é o de legítima tanto a herança com testamento como sem testamento, já que as duas são disciplinadas pelo ius civile. Assim que, para os romanos, legitima hereditas é a herança do direito civil contraposta a bonorum possessio ou sucessão pretória (Schulz, 1960, p. 205).

A delação testamentária prevalece sobre a intestada (Alves, 2007, p. 715). Segundo um antigo princípio romano, a sucessão testamentária e a sucessão intestada são absolutamente incompatíveis, e por causa disso se desdobram as seguintes consequências: 1) Se houver testamento, não procede a delação $a b$ intestato; 2) Quando o herdeiro é instituído em uma parte do patrimônio (pro parte) o restante do total se acresce aquele (Alves, 2007, p. 715).

Essa situação se explica e se justifica pela primitiva concepção de herança como transmissão da posição política familiar uma e indivisa. Quando pelo passar das épocas históricas a herança admite outras funções (patrimoniais) é possível nomear vários herdeiros, ainda que o título seja o mesmo (Kaser, 1999, p. 391). Surgida nos começos do Império, a chamada "sucessão legítima contra testamento" a regra da incompatibilidade entre ambas as formas de sucessão sofre importantes modificações (Schulz, 1960, p. 254). Passa-se a observar, ainda que sumariamente, ambas as possibilidades de delação em linhas gerais no direito romano.

\section{A Sucessão Testamentária no Direito Romano}

Os textos apresentam duas definições de testamento (testamentum). Uma, atribuída a Ulpiano (Liber Singularis regularum, $\mathrm{XX}, 1)$ :

Testamentum est uoluntatis nostrae iusta sententia de eo, sollemniter factum, ut post mortem nostram valeat. O testamento é a declaração, conforme o direito, da nossa vontade, feito de forma solene para que valha depois de nossa morte. 
Outra, atribuída a Modestino (D.XXVIII.1.1).:

Testamentum est uoluntatis nostrae iusta sententia de eo quod quis post mortem suam fieri velit.

O testamento é a declaração de nossa vontade, conforme o direito, a respeito daquilo que cada qual quer que se faça depois de sua morte.

O testamento é um ato solene e de última vontade pelo qual se nomeia herdeiro e se podem fazer outras disposições de caráter patrimonial ou pessoal, sendo um ato de direito civil e por isso privativo dos cidadãos romanos (D'Ors, 2006, p. 329). Porém, esta regra é atenuada com o fideicomisso aberto a todas as gentes. O testamento advém de um ato do testador e, por isso, se classifica como ato unilateral, não existindo de forma nenhuma o concurso de vontades (Alves, 2007, p. 716).

As formas mais antigas de testar são o Testamentum calatis comitiis que era outorgado perante os comícios por cúrias, convocados em duas datas fixas ao ano, com significado público-religioso, e em tempos de paz. Segundo Moreira Alves (2007, p. 717):

O testamento calatis comitiis, que era utilizado em tempo de paz, se fazia diante dos comícios por cúrias, sob a presidência do Sumo Pontífice (ou, às vezes, segundo parece, do Rex Sacrorum), os quais se reuniam duas vezes por ano: provavelmente, em 24 de março e em 24 de maio. Como os textos são parcos de informes sobre essa forma primitiva de testamento, há controvérsia entre os romanistas acerca do conteúdo desses testamentos e do papel desempenhado, para sua feitura, pelo povo reunido nos comícios.

Havia ainda o Testamentum in procinctu que era outorgado quando o homem saía para a batalha, ante ao exército em pé de guerra. Já as formas de testar do direito clássico são o Testamentum per aes et libram que se dava quando quem não tinha feito testamento, e estava em perigo de morte, mancipava todo o seu patrimônio a um amigo, rogando-lhe que entregasse à pessoa destinada no testamento. Nesta modalidade primitiva, havia a presença do "comprador da herança" (familiae emptor) que se comprometia de passar ao herdeiro instituído. No desenrolar desta modalidade aparece o instituto da nuncupatio, nomeação em público do herdeiro (Alves, 2007, p. 718):

O testamento nuncupativo é também (à semelhança do testamento pretoriano) uma simplificação do testamento per aes et libram; mas, à diferença do testamento pretoriano, é uma forma de testamento reconhecida pelo ius ciuile, e portanto, a pessoa nele designada para receber é heres (herdeiro), e não, simplesmente, bonorum possessor. O testamento nuncupativo se faz por declaração oral do 
testador, na presença de, a princípio, cinco testemunhas (e isso porque, das sete exigidas no testamento pretoriano, duas eram o familiae emptor e o libripens, as quais, com a desnecessidade da mancipatio para a celebração do testamento nuncupativo, deixam de ser exigidas), e, posteriormente, de sete.

No direito pós-clássico caem em desuso essas modalidades, substituídas pelo Testamento Privado. O testamento nuncupativo (nomeação oral do herdeiro), o testamento ológrafo (testamento escrito a mão), o testamento tripertium (junção de três vertentes: ius civile, bonorum possessio secundum tabulas e as constituições imperiais). Também pelo Testamento Público: O testamento apud acta conditum, o testamento oblatum principi. Existiam ainda os Testamentos Especiais ou Extraordinários e o Testamento Militar, além do Testamentum ruri conditum (feito no meio rural), o Testamentum pestis tempore, feito em tempo de peste, se o testador está atacado por doença contagiosa; o Testamentum parentum inter líberos, que se trata de testamento de pai para filhos (segundo Justiniano não precisava de testemunhas) e o Testamento Militum que era o testamento dos soldados. Há a dispensa de formalidades e também de algumas regras importantes relativas ao testamento em geral. Primeiro, porque a regra de que ninguém pode falecer em parte testado em parte não, não se aplica. Depois, porque além do soldado poder fazer vários testamentos, pode instituir herdeiro para uma coisa certa (Alves, 2007, p. 721).

No direito romano, para que alguém possa dispor de seu patrimônio para depois da sua morte, é preciso que tenha aptidão para testar. Em princípio, isso inclui todas as pessoas sui iuris, mas no curso do direito romano, houve amenização deste rigor. Entre os sui iuris ainda havia restrições: a mulher não podia fazer testamento colatis comitti nem in procinctu porque ela não podia participar de comícios nem ir à guerra. Algumas mulheres (libertas e não ingênuas) podiam pedir para o seu tutor para fazer a solenidade do testamento. Quando acabou a tutela das mulheres, elas puderam testar de forma legítima (Kaser, 1999, p. 387). Além disso, é preciso verificar a capacidade de fato para testar: não possuíam capacidade de fato para testar os impúberes, os loucos, os pródigos. Da mesma forma, a capacidade para ser beneficiado em um testamento tem regras específicas no direito romano. Em princípio, podem ser instituídos herdeiros no testamento tanto a pessoa física como o nascituro e a divindade. De outra sorte, são incapazes de serem instituídos herdeiros em testamento: a mulher pela previsão da lex voconia, as pessoas incertas, os intestáveis entre outros (Alves, 2007, p. 723). 
Por outro lado, no direito romano o testamento pode conter diferentes disposições de ordem patrimonial ou pessoal, como por exemplo, a instituição de herdeiro, as manumissões, a designação de tutor, os legados e os fideicomissos (Kaser, 1999, p. 385). De todas essas citadas, a primeira (instituição do herdeiro) é a única imprescindível, e regras deveriam ser rigorosamente observadas, como por exemplo, o local onde deverá estar a nomeação do herdeiro: na "testa" do testamento. Tudo o que tiver antes é inválido (caput et fundamentum totius testamenti, Gaio, p. 2.229). Também se deve observar que a instituição do herdeiro é feita in perpetuum: para sempre. O herdeiro deve ser instituído para receber toda a herança, e não apenas uma parte dela (ninguém pode falecer em parte testatus e em parte intestatus) (Alves, 2007, p. 720).

Além disso, no direito romano, o testamento pode adoecer de um vício ou defeito que impede desde o seu princípio a sua própria existência. $\mathrm{O}$ testamento afetado por invalidade radical ou inicial recebe qualificações diversas (Kaser, 1999, p. 389).

Trata-se de testamentum iniustum quando na outorga não se observa a forma devida ou, ainda, quando falta o ius testamenti factio. Diz-se inutile ou nullius momenti o testamento no qual os sui heres são preteridos. Várias denominações recebe também o testamento que, sendo inicialmente inválido, é depois anulado: chamase testamentum irritum factum quando sobrevém a perda da capacidade jurídica, salvo que, tratando-se de capitis demunutio máxima, sobrevenha a aplicação do post-liminium. Testamentum ruptum é a expressão empregada quando nasce um heres suus depois da morte do testador, e este não o tinha levado em conta, seja para instituí-lo ou deserdá-lo. Assim, o testamento é ineficaz quando, embora válido, não produz os seus efeitos em virtude de, por exemplo, o herdeiro não ter aceito a herança (fala-se aqui de testamento desertum ou destitutum). Ainda, porque é um ato de última vontade, o testamento pode ser revogado, que segundo o ius civile só pode acontecer com a sobrevinda de um novo testamento. Mesmo que o segundo não produza nenhum efeito, o testamento revogado está acabado (Alves, 2007, p. 725).

\section{A Sucessão Ab Intestato no \\ Direito Romano}

O caráter da primitiva organização familiar implica na necessidade de alguém suceder o pater falecido no seu supremo poder que tem sobre o grupo, e isso se dá com a instituição do herdeiro no testamento. Pode, porém, acontecer de o pater falecer antes de designar o seu sucessor, o que, se ficasse sem regulação seria muito grave para os preceitos da época. Por isso, desde os mais remotos tempos 
existe um modo de regular a sucessão de quem faleceu intestato, isso é, sem testamento, ou com testamento inválido. É, então, uma forma supletiva, subordinada, excepcional, e não se baseia nos vínculos de sangue, mas nas relações de agnação e, ainda, gentílicas. Hoje chamamos esta modalidade de "sucessão legítima" (Alves, 2007, p. 742):

Somente o cidadão romano é que, com sua morte, dá ensejo à abertura da sucessão ab intestato, uma vez que essa sucessão foi organizada pelo ius ciuile, cujos preceitos só se aplicavam aos cidadãos romanos. A sucessão ab intestato dos estrangeiros é disciplinada pela sua lei nacional, e não pelo direito romano. Por outro lado, a princípio, além de cidadão romano, é necessário que o de cuius se sui iuris; a partir do século IV d.C., começa-se a admitir a sucessão ab intestato do filius familias (pessoa alieni iuris, no tocante ao pecúlio, e Justiniano, na Novela CXVIII, admitindo que o filius familias possa ter herdeiros $a b$ intestato, o equipara, nesse particular, ao paterfamilias.

Como já foi visto, preconiza a Lei das XII Tábuas: "Se morre intestado quem carece de um 'herdeiro seu', tenha a herança o agnado mais próximo. Se não existe agnado, recorram a herança aos gentis". Sui Heredes são aqueles que estavam sob o pátrio poder ou sob a manus do de cujus: os filhos vivos, inclusive adotivos e não emancipados, seus netos caso tives- sem o pai morto ou com capitis deminutio, bisnetos na mesma situação, a mulher in manus. Assim, era o parentesco agnatício que determinava a qualidade de heredes. Para estes sui heredes não havia a possibilidade de renunciar a herança, que adquiriam automaticamente. Se faltasse o heredes sui, é chamado o agnado mais próximo. A mulher sui iuris, ao falecer, somente tem como heredes legitimi os agnados próximos e, na falta deles, os gentiles, porque a mulher nunca poderia ser pater familias, e por isso não poderia ter heredes sui, e assim o agnado é o primeiro a ser chamado a sucedê-la ab intestato (Kaser, 1999, p. 374).

O sistema do ius civile era muito restrito e a prática da valorização do parentesco cognatício foi sendo respeitada. Assim, a reação do pretor ao sistema da sucessão ab intestato da Lei das XII Tábuas se fez mediante as bonorum possessiones ab intestato (Kaser, 1999, p. 375). Num primeiro momento, as bonorum possessios não eram protegidas contra o heredes legitimus que recuperava a herança pelas ações do ius civile, mas, pouco a pouco, passaram a ser concedidas cum re, isso é, protegidas contra os herdeiros legítimos. Pessoas a quem eram deferidas a bonorum possessio: 1. unde liberi: os sui heredes do ius civile e mais os filhos emancipados, desde que tivessem nascido de justas núpcias, não estivessem sob 
a potestas de outro pater. 2. unde legitimi: todos os legítimos do ius civile eram novamente chamados. 3 . unde cognati: nesta terceira classe, colocavam-se os cognados do falecido até o sexto grau; 4. unde vir et uxor: quarta e última classe, encontravam-se o cônjuge que sobrevivera ao de cujus, desde que o casamento fosse legítimo. Essa ordem era observada, e o pretor dava 100 dias para cada classe sucessivamente requerer a bonorum possessio (Alves, 2007, p. 747).

A tendência a valorização da família natural prevalece na época imperial (Kaser, 1999, p. 377). Nessa época, os senatusconsultos Tertuliano e Orficiano estabeleceram a sucessão $a b$ intestato recíproca, como herdeiros civis, entre mães e filhos, independentes de serem parentes agnados. Senatusconsulto Tertuliano: (117138 d.C.), chamou a mãe à sucessão ab intestato dos filhos, desde que ela gozasse do ius liberorum (três filhos se ingênua, quatro filhos se liberta), e também que o filho de cuja sucessão se trata tivesse sido ingênuo e sui iuris. Se preenchesse estes requisitos, a mãe é colocada na frente dos agnados do filho, com algumas exceções. Senatusconsulto Orficiano (178 d.C) chamou os filhos (ainda que nascidos de matrimônios diversos) à sucessão nos bens de sua mãe e na frente de todos os agnados dela, mas não estendeu esse chamado aos netos (Alves, 2007, p. 748).
No Corpus Iuris Civilis, as regras que vinham dos períodos anteriores vigoraram com pequenas modificações, mas o sistema da reunião dos princípios até então válidos, não eram harmônicos e não correspondiam às tendências do direito justinianeu. Então, Justiniano promoveu a reforma com as Novelas 118 e 127. Não se faz mais distinção entre agnados e cognados, pessoas sui iuris e alieno iuris, homens e mulheres, parentes da linha masculina e da linha feminina. Acontece a assimilação das bonorum possessiones à sucessão ab intestato, falando-se somente em hereditas (Kaser, 1999, p. 378). Essas mudanças determinaram o modelo que chegou até nós. $\mathrm{E}$, assim, os heredes legiti$m i$ são agrupados em quatro classes: $1^{\text {a }}$ classe: os descendentes: todos os descendentes do de cujus, que se encontrem ou não sob sua potestas; $2^{\mathrm{a}}$ classe: os ascendentes, paternos e maternos, irmãos e irmãs germanos e seus filhos. Entre os ascendentes, o grau mais próximo exclui o mais remoto. Se houver mais de um ascendente na mesma linha, a herança se divide por cabeça, se em graus diferentes, por estirpe; $3^{\mathrm{a}}$ classe: a dos irmãos e das irmãs consanguíneos ou uterinos e seus filhos (são os meio irmãos: só de pai, consanguíneos; só de mãe, uterinos); $4^{\mathrm{a}}$ classe: a do colateral mais próximo, obedecendo a regra segundo a qual o mais próximo exclui o mais remoto (Alves, 2007, p. 751). 


\section{CONCLUSÃO}

Como no direito de família, o direito sucessório tem seu fundamento num fato biológico: se o homem não fosse mortal, o direito hereditário careceria de sentido. O homem sempre quer saber com quem ficará tudo aquilo que uma determinada cultura entende por imperecível, o que não desaparece com a pessoa. Corresponde-se a um comportamento instintivo de deixar para os descendentes como modo de garantir-lhe a sobrevivência, e assim o direito hereditário ratifica o caráter da família como centro assistencial. Essas brevíssimas linhas pretenderam, antes de tudo, apresentar um sumário explicativo das principais manifestações civilizatórias da Antiguidade no seu perfil sucessório.

Para tanto, se observou que o direito sucessório no Antigo Egito, diante da envergadura de sua cultura, não pode ser retratado nas fontes de direito, já que manifestadas em poucos e raros documentos que chegaram para nós. Sabe-se, porém que como direito religioso, manifestado na figura de grandes e poderosos deuses, o Egito viveu um direito mítico que pode significar a harmonia pretendida pelos deuses para os homens.

No direito babilônico, a figura de um dos maiores reis da Antiguidade transformou o Poder em Direito promulgando o seu código: O Código de Hammurabi. Por isso, o direito suces- sório, como ramo do caráter jurídico de todo o conjunto de leis, é afirmado e desenvolvido na forma mais plena de proteção da família e da propriedade.

Já o direito hebreu foi caracterizado pelo caráter religioso das disposições jurídicas que, por fenômenos históricos, puderam chegar até os dias atuais tendo influenciado diversos direitos formados no seu percurso histórico, como o direito canônico por exemplo. Nesse conjunto de regras, o direito sucessório demonstrou ser protecionista não só da família (clã), mas, principalmente, da mulher.

Sobre a Grécia Antiga faltam fontes precisas para demonstrar o conteúdo exato do direito sucessório, mas é certo que suas leis consagravam um caráter de disposição por parte do titular do patrimônio, mesmo em detrimento da linha sanguínea ou de parentesco.

No direito Romano, a ideia de sucessão pode tomar forma e ser preparada para ser perpetuada na História. Desde terminologias até conteúdos mais densos correspondentes ao direito do indivíduo de passar o patrimônio após a sua morte, no direito ocidental, têm a sua origem no direito romano. É algo comum a todos os ordenamentos o conteúdo patrimonial das titularidades e o fenômeno da sua transmissão mortis causa, da mesma forma, é tratado de maneira especifica conforme a cultura de cada povo. O ocidente, porém, tem a marca do direito romano. 
Nestas acintosamente breves linhas não se pretendeu completar o tema, mas, ao contrário, mostrar um sumário tópico sobre como eram as principais linhas de direito sucessório em Roma, mesmo que sem considerar os treze séculos de transformações sociais, politicas, econômicas e, evidentemente, jurídicas pelas quais passou tal direito.

Resta, por fim, asseverar que é verdade que as necessidades da vida humana não reclamam direitos para além da sua existência. Mas o próprio direito sucessório representa um transpassar de direitos para depois do fim da existência humana. Essa expressão da vida nada mais é do que fruto de um estágio cultural do povo que a emprega. Diante disso, a maravilha é perceber a proximidade jurídica que nos encontramos em relação a povos tão distantes no tempo.

\section{REFERÊNCIAS}

ALBERGARIA, Bruno. Histórias do Direito. 2. ed. São Paulo: Atlas, 2012.

ALVES, José Carlos Moreira. Direito Romano. 14. ed. Rio de Janeiro: Forense, 2007.

BONFANTE, Pietro. Istituzioni di Diritto Romano. Torino: Giappichelli, 1946.

BOUZON, Emanuel. O Código de Hammurabi. 4. ed. Petrópolis: Vozes, 1987.

CASTRO, Flávia Lages. História do Direito Geral e Brasil. Rio de Janeiro: Lúmen Juris, 2008.

CRUZ, Guilherme Braga da. Obras Esparsas. V. I: Estudos de História do Direito. Direito Antigo, $1^{a}$ parte. Coimbra: Faculdade de Coimbra, 1979.

D'ORS, Alvaro. Derecho Privado Romano. Pamplona: EUNSA, 2006.
FUSTEL de COULANGES, Numa Denis. A Cidade Antiga. Trad. de Cretella Jr. São Paulo: Revista dos Tribunais, 2012.

GAGLIARDI, Lorenzo. Per um'interpretazione della legge di Solone in materia sucessória. In: DIKÉ, Rivista di storia del diritto Greco, Ed. ellenistico, n. 5, 2002, p. 5-59.

GILISSEN, John. Introdução Histórica ao Direito, 5. ed. Lisboa: Fundação Calouste Gulbenkian, 2008.

HATTENHAUER, Hans. Conceptros Fundamentales del Derecho Civil. Barcelona: Editorial Ariel, 1987. KASER, Max. Direito Privado Romano. Lisboa: Fundação Calouste Gulbenkian, 1999.

LEÃO, Delfim. Sólon e a Legislação em matéria de direito familiar. In: 
DIKÉ, Rivista di storia del diritto Greco ed ellenistico, n. 8, 2006, p. 5-31.

LOPES, José Reinaldo Lima. $O D i-$ reito na História. São Paulo: Atlas, 2008.

MEYER, Eduard. El Historiador y la Historia Antigua. Mexico: Fondo de Cultura Económica, 1955.

NASCIMENTO, Walter Vieira do. Lições de História do Direito. 15. ed. Rio de Janeiro: Forense, 2009. PALMA, Rodrigo Freitas. $O$ Direito antes de Roma. Goiânia: Kelps, 2001.
PALMA, Rodrigo Freitas. História do Direito. 4. ed. São Paulo: Saraiva, 2011.

PEDROSA, Ronaldo Leite. Direito em História. 6. ed. Rio de Janeiro: Lumen Juris, 2008.

SCHULZ, Fritz. Derecho Romano Clasico. Trad. José Santa Cruz Teigeiro. Barcelona: Bosch, 1960. SOUZA, Marcos Antonio de. O direito hebraico antigo. In: Fundamentos de História do Direito. Antonio Carlos Wolkman (Organizador). 4. ed. Belo Horizonte: Del Rey, 2008. 